\title{
Methemoglobin measure in adult patients with sickle-cell anemia: influence of hydroxyurea therapy
}

\author{
Dosagem de metemoglobina em pacientes adultos com anemia \\ falciforme: influência do tratamento com bidroxiureia
}

Marilia Rocha Laurentino'; Teresa Maria de Jesus Ponte Carvalho²; Talyta Ellen de Jesus dos Santos; Maritza Cavalcante Barbosa ${ }^{3}$; Thayna Nogueira dos Santos ${ }^{1}$; Romélia Pinheiro Gonçalves ${ }^{4}$

\begin{abstract}
Introduction: Hemoglobin S (HbS) is unstable hemoglobin that easily oxidizes, causing methemoglobin (MetHb) increased production in patients with sickle-cell anemia (SCA). Objectives: To determine MetHb levels and the influence of hydroxyurea (HU) therapy on this marker in patients with SCA. Materials and methods: Blood samples from 53 patients with SCA at the steady-state, with and without HU therapy, and 30 healthy individuals were collected to evaluate MetHb levels. The MetHb measurement was performed by spectrophotometry. Complete blood count, $\mathrm{HU}$ measurements, and fetal hemoglobin (HbF) and $\mathrm{HbS}$ concentrations were taken from medical records. Results: MetHb levels were statically higher in patients with SCA when compared to control group $(p<0.001)$. There was no statistical difference in MetHb level between SCA patients, either using or not HU. We obtained a positive correlation between MetHb measurements and HbS concentration $(r=0.2557 ; p=0.0323)$. Conclusion: HbS presence favored hemoglobin breaking down, and consequently increased MetHb production. Treatment with HU, however, did not influence the levels of this marker.
\end{abstract}

Key words: anemia; sickle-cell disease; methemoglobin; hydroxyurea.

\section{INTRODUCTION}

Sickle-cell anemia (SCA) is one of the most common inherited blood disorders worldwide, with the highest incidence of hemoglobinopathies in Brazil $^{(7,12)}$. It is manifested in presence of hemoglobin S (HbS) in homozygous, and resulted from a mutation in the beta-globin gene that leads to glutamic acid (GAG) being substitution by another amino acid, valine $(\mathrm{GTG})^{(8)}$. With this change, the hemoglobin molecule spatial structure is modified, forming aggregates of filaments that polymerize and precipitate, leaving the cell with sickle appearance. This phenomenon is largely responsible for the clinical features presented of patients with $\mathrm{SCA}^{(24)}$.

Another important factor in disease is hemolysis caused by oxidative degradation of HbS. Patients with SCA have a greater tendency to oxidative stress and this can be attributed to increased instability of HbS, promoting an autoxidation of $\mathrm{Fe}^{2+}$ in hemoglobin, with consequent formation of methemoglobin $(\mathrm{MetHb})^{(10)}$.

MetHb is physiologically produced when occurs hemoglobin oxidation, and it is eliminated naturally by the reducing systems, maintaining serum levels below $2 \%{ }^{(16)}$. Its excess occurs in the presence of redox imbalance, and can be caused by excessive hemoglobin oxidation (increased production, as occurs in SCA, since HbS tend to suffer greater susceptibility of oxidation), or because of decreasing the activity of the reducing enzymes (reduced metabolism) $)^{(16,19)}$.

Hydroxyurea (HU) is a chemotherapy drug used in myeloproliferative disorders and neoplastic diseases. This drug has the ability to prevent the formation of $\mathrm{HbS}$ polymers and increase levels of fetal hemoglobin ( $\mathrm{HbF})$. The $\mathrm{HbF}$ is an important inhibitor of the HbS polymerization, inhibiting the hemoglobin oxidation and consequent formation of MetHb $\mathrm{b}^{(2,13)}$.

First submission on 06/02/14; last submission on 02/04/14; accepted for publication on 02/04/14; published on 20/06/14

1. Pharmacist; MS graduating degree in Pathology Program at Universidade Federal do Ceará (UFC).

2. PhD in Toxicology at Faculdade de Ciências Farmacêuticas de Ribeirão Preto; assistant professor II at UFC.

3. MS in Pharmaceutical Sciences at UFC; PhD graduating degree in Pharmaceutical Sciences at UFC.

4. PhD in Pharmacy, Clinical Analysis branch at Universidade de São Paulo (USP); associate professor at UFC. 
In this context, the study aimed to determine the levels of methemoglobin and the influence of treatment with hydroxyurea on this marker in patients with SCA.

\section{MATERIALS AND METHODS}

\section{Subjects}

A cross-sectional study was carried out in a total of 53 patients with SCA. All patients were attended at the hematology service of a referral hospital in Fortaleza (Ceará, Brazil) between July 2013 and September 2013. The patients were diagnosed by clinical and laboratory criteria, and molecular analysis; they were separated in two groups according to HU use. The control group consisted of 30 healthy individuals. Informed consent was obtained from all patients and controls. The study was approved by the Research Ethics Committee of the hospital and was conducted in accordance with the Declaration of Helsinki as revised in 2008.

\section{Laboratory data}

MetHb levels was measured spectrophotometrically in hemolyzed whole blood, according to the methodology proposed by Naoum et al. in $2004^{(14)}$, using whole blood samples collected with anticoagulant ethylenediamine tetraacetic acid (EDTA). Epidemiological and laboratory data (blood count and $\mathrm{HbF}$ and HbS concentrations) and information regarding the use of $\mathrm{HU}$ were obtained from medical records.

\section{Statistical analysis}

Statistical analysis was performed by GraphPad Prism 5.0 software using the Kruskal - Wallis, Mann-Whitney test and paired $t$ test. Spearman's correlation was used to explore the association between MetHb levels and $\mathrm{HbS}$ and $\mathrm{HbF}$ concentrations. The significance level was set at $5 \%(\phi<0,05)$.

\section{RESULTS}

Our study consisted of 53 patients with SCA, aged 18-59 years, with average age of 33.4 years. Regarding gender, 33 (62.26\%) were female and $20(37.74 \%)$ were male. Concerning HU therapy, $35(66.03 \%)$ patients used it while 18 (33.97\%) were not treated with this drug.

The demographic, clinical and hematological data are presented in the Table below, where it is possible to observe some significant differences between the two groups of SCA patients, treated and not treated with HU. Patients using HU showed statistical increase in mean corpuscular volume (MCV), mean corpuscular hemoglobin (MCH), leucocytes count and $\mathrm{HbF}$ concentration, and a decrease in platelet count compared to untreated patients.

TABLE - Characteristics and clinical details of patients with SCA

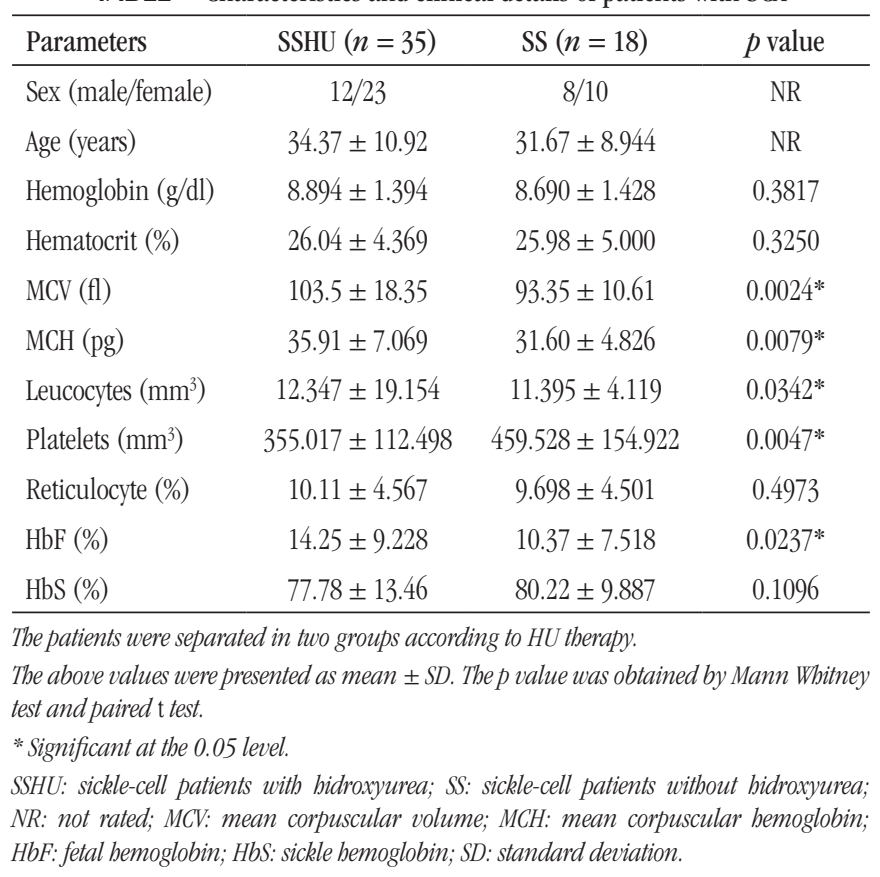

The average dose of $\mathrm{HU}$ used by patients with SCA was $12.44 \mathrm{mg} / \mathrm{kg}$ /day, with a minimum dose of $7.140 \mathrm{mg} / \mathrm{kg} /$ day and a maximum of $21.42 \mathrm{mg} / \mathrm{kg} /$ day. The average treatment time was 39.37 months, with patients treated for a minimum of 6 months and maximum 80 months.

Patients with SCA had a MetHb mean ( \pm standard deviation $[S D])$ of $3.873 \pm 1.145$, while the control group had a mean $( \pm S D)$ of $2.454 \pm 0.4673$. It was found that the SCA patients group has levels of this marker statistically higher than the control group (Figure 1).

Regarding the use of $\mathrm{HU}$, patients in therapy had a MetHb mean $( \pm$ SD) of $3.781 \pm 1.033$, while patients without the use of HU showed MetHb mean $( \pm$ SD) of $4.053 \pm 1.351$. The comparison of means between SCA patients with and without HU showed no statistically significant result $(\phi=0.1058)$, although the average of MetHb was higher in the latter group of patients (Figure 2).

Patients taking $\mathrm{HU}$ at a dose $<8 \mathrm{mg} / \mathrm{kg} /$ day did not show statistically significant levels of MetHb compared to those taking HU dose $\geq 8 \mathrm{mg} / \mathrm{kg} /$ day $(\phi=0.4242$ ). Regarding the duration of $\mathrm{HU}$ therapy, patients taking it for a period greater than or equal to 40 months showed no statistical difference in MetHb levels, when compared to those taking HU therapy for less than 40 months $(p=0.4086)$. 


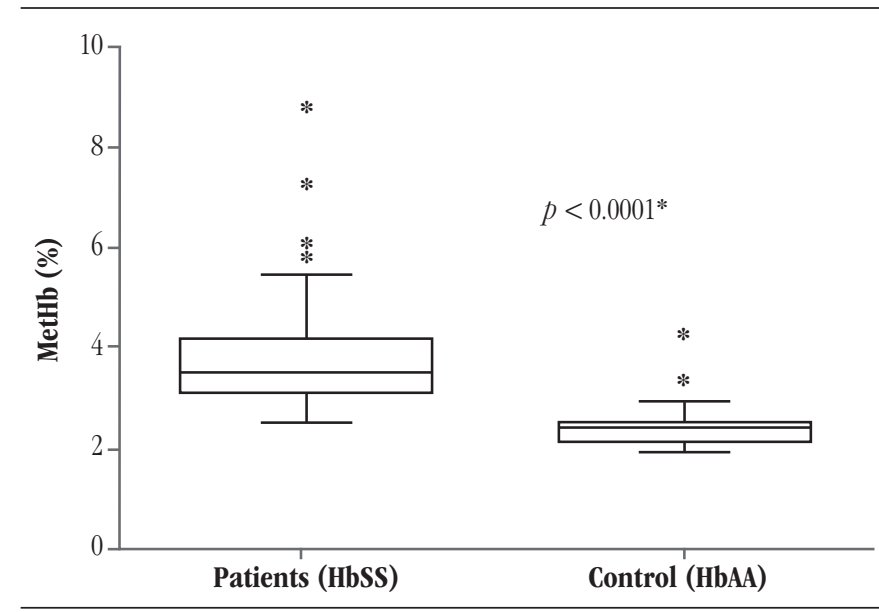

FIGURE 1 - Comparison of MetHb levels between SCA patients and control group *Significant at the 0.05 level. p value obtained by Mann Whitney test. Results presented as median.

MetHb: methemoglobin; SCA: sickle-cell anemia; HbSS: patients with SCA; HbAA: healthy subjects.

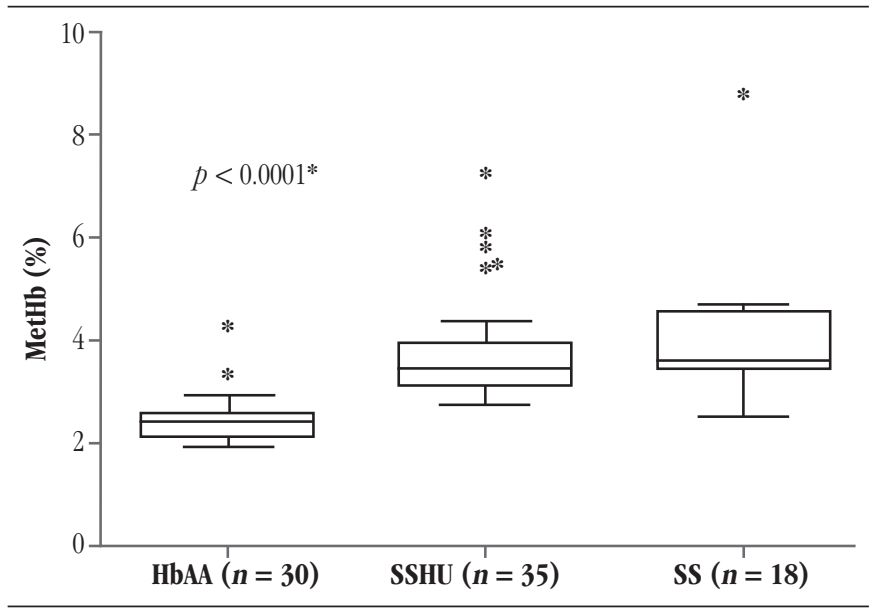

FIGURE 2 -MetHb levels in patients with SCA with and without HU therapy (SSHU and SS, respectively), and in the control group

p value obtained by Kruskal-Wallis test. Statistically significant difference between groups SSHU and control group (HbAA), and SS and the control group (HbAA - bealthy subjects); SSHU: patients with SCA treated with HU; SS: patients with SCA untreated with HU. Results presented as median

*Significant at the 0.05 level.

MetHb: methemoglobin; SCA: sickle-cell anemia; HU: hydroxyurea.

There was a positive correlation between the concentration of HbS and MetHb levels $(r=0.2557 ; p=0.0323)$ (Figure 3). No correlation was observed between $\mathrm{HbF}$ concentration and MetHb levels $(r=-0.06307 ; p=0.3268)$ (Figure 4).

\section{DISCUSSION}

The HU treatment has been associated with clinical and hematologic improvement of patients with SCA, with multiple

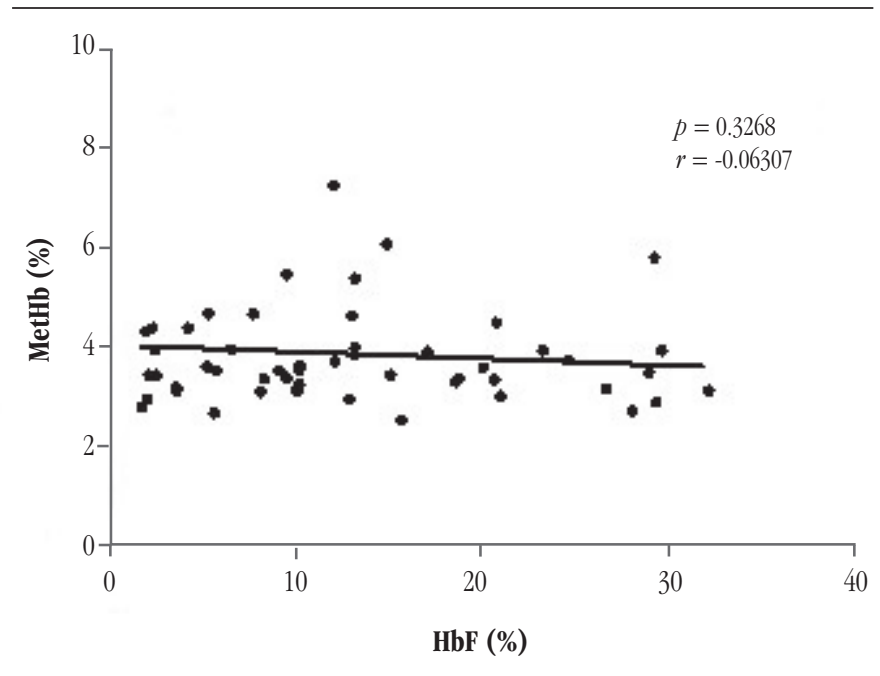

FIGURE 3 - Correlation between MetHb levels and HbF concentration in patients with SCA Spearman correlation test

MetHb: methemoglobin; HbF: fetal hemoglobin; SCA: sickle-cell anemia.

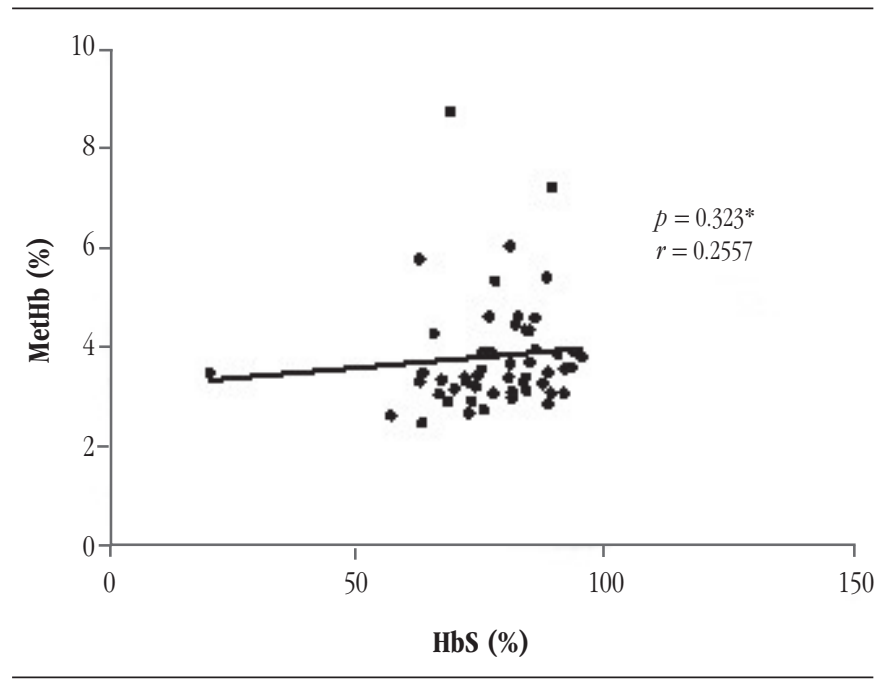

FIGURE 4 -Correlation between MetHb levels and HbS concentrations in patients with SCA Spearman correlation test

*Significant at the 0.05 level.

MetHb: methemoglobin; Hbs: S hemoglobin; SCA: sickle-cell anemia.

effects on the erythrocyte lineage. In our study, patients treated with HU presented increased MCV, MCH, total leukocyte count, and a significant decrease in platelet count compared to untreated patients. Permanence of high MCV, even after the use of $\mathrm{HU}$, was also observed in sickle-cell patients using $\mathrm{HU}$ in previous studies $^{(3,17,22)}$. The HU has also been associated with a decrease in platelet count, total leukocyte reduction and $\mathrm{MCH}$, however, only the first result was observed in our study ${ }^{(5,6,20)}$.

Increased levels of $\mathrm{HbF}$ in patients using $\mathrm{HU}$ was also observed in other studies ${ }^{(20,21)}$. It is very relevant to patient clinical status, because 
$\mathrm{HbF}$ acts as a protective agent against sickling of red blood cells, reducing the process of hemolysis and anemia, and consequently is associated with decreased mortality in these patients ${ }^{(2,4,18)}$.

The results also showed that SCA patients showed a significant increase in MetHb in relation to the healthy individuals group. The increased formation of MetHb by sickle-cell patients is due to the presence of $\mathrm{HbS}$. It has been shown that hemoglobin has an increased susceptibility to undergo oxidation, and when it is subjected to low oxygen tensions, transforming discoid erythrocytes into sickle erythrocytes, increasing the production of MetHb, hemicromos, or products of heme; and causing globin S precipitation in oxidized form of Heinz bodies ${ }^{(13,15,19)}$. Naoum $\mathrm{e}$ Souza ${ }^{(15)}$, Allen et al.$^{(1)}$ and Silva Filho ${ }^{(19)}$ also observed an increase of MetHb in patients with hemoglobinopathies.

Although HU has proven clinical efficacy, reducing the tendency of $\mathrm{HbS}$ polymerization, and subsequent vaso-occlusive phenomena ${ }^{(9)}$, some factors on the performance of this drug in patients with SCA (as the optimal therapeutic dose, action mechanism, and intense variability in therapeutic response) are not yet understood. In our study, although patients treated with HU have presented average dosage of MetHb less than untreated patients, this result was not statistically relevant, and this can be explained by variations in individual response to the drug ${ }^{(11,23)}$.
$\mathrm{HbF}$ increase is an important modulation factor in $\mathrm{HbS}$ polymerization and in clinical consequences to SCA patients. It is particularly useful in protecting against the sickling process and decreasing the hemolysis degree ${ }^{(4,13,24)}$. Although not significant, in our study MetHb levels showed a decreasing trend in patients with SCA who had higher HbF concentrations. The patients in this study showed a wide variation in the HbF concentration, hindering a possible correlation with the levels of MetHb.

The concentration of $\mathrm{HbS}$ in our study showed significant direct correlation with the levels of MetHb. Patients with higher concentrations of $\mathrm{HbS}$ were also those who had high levels of MetHb, showing the relationship between high concentrations of sickle hemoglobin and increased oxidative degradation, with consequent increase in the production of MetHb for patients with SCA.

\section{CONCLUSION}

The results of this study support the hypothesis that polymerization and the oxidative process that $\mathrm{HbS}$ is constantly subjected contributes to the increase of hemolysis in SCA patients, with a consequent increase in the formation of oxidative products such as MetHb. Treatment with HU, however, does not seem to influence the levels of this marker.

\section{RESUMO}

Introdução: A hemoglobina S (HbS) é uma hemoglobina instável que facilmente se oxida, causando aumento da produção de metemoglobina (MetHb) em pacientes com anemia falciforme (AF). Objetivos: Determinar os níveis de MetHb e verificar a influência do tratamento com a bidroxiureia (HU) sobre as dosagens desse marcador em pacientes com AF. Materiais e métodos: Amostras de sangue de 53 pacientes adultos com AF em estado basal, em uso ou não de HU, e 30 indivíduos sandáveis foram coletadas para avaliar os niveis de MetHb. A dosagem de MetHb foi realizada pelo método espectrofotométrico. Os parâmetros hematológicos, a dosagem de HU e a concentração de hemoglobina $F(H b F)$ e HbS foram retirados dos prontuários médicos. Resultados: Niveis de MetHb apresentaram-se mais elevados estatisticamente em pacientes com AF em relação ao grupo-controle ( $\mathrm{p}<0,0001)$. Não foi verificada diferença estatística nos niveis de MetHb entre pacientes em uso ou não de HU. Observou-se correlação positiva entre as dosagens de MetHb e a concentração de HbS ( $\mathrm{r}=0,2557 ; \mathrm{p}=0,0323)$. Conclusão: A presença da HbS favoreceu a degradação da hemoglobina, causando elevação da produção de MetHb. Tratamento com HU, entretanto, não influenciou nos niveis desse marcador.

Unitermos: anemia falciforme; metemoglobina; hidroxiureia.

\section{REFERENCES}

1. ALLEN, A. et al. Methemoglobinemia and ascorbate deficiency in hemoglobin E $\beta$ thalassemia: metabolic and clinical implications. Blood, v.120, n. 15, p. 2939-44, 2012.
2. BANDEIRA, F. M. G. C. et al. Hidroxiureia em pacientes com síndromes falciformes acompanhados no Hospital Hemope, Recife-PE. Rev Bras Hematol Hemoter, v. 26, n. 3, p. 189-94, 2004.

3. BORBA, R. et al. Reticulocyte parameters and hemoglobin f production in sickle cell disease patients undergoing hydroxyurea therapy.J Clin Lab Anal, n. 17, v. 2, p. 66-72, 2003. 
4. FIGUEIREDO, M. S. Fatores moduladores da gravidade da evolução clínica da anemia falciforme. Rev Bras Hematol Hemoter, n. 29, v. 3, p. 215-7.

5. CANÇADO, R. D. et al. Protocolo clínico e diretrizes terapêuticas para uso de hidroxiureia na doença falciforme. Rev Bras Hematol Hemoter, v. 31, n. 5, p. 361-6, 2009 .

6. COVAS, D. T. et al. Effects of hydroxyurea on the membrane of erythrocytes and platelets in sickle cell anemia. Haematologica, n. 89, v. 3, p. 273-80, 2004.

7. GALIZA NETO, G. C.; PITOMBEIRA, M. S. Aspectos moleculares da anemia falciforme. J Bras Patol Med Lab, v. 39, n. 1, p. 51-6, 2003.

8. GARANITO, M. P. Hemoglobinopatias - interpretação do teste de triagem neonatal. Pediatria (São Paulo), n. 30, v. 3, p. 172-6, 2008.

9. GLOVER, R. E. et al. Detection of nitrosyl hemoglobin in venous blood in the treatment of sickle cell anemia with hydroxyurea. Molecular Pharmacology, v. 55, n. 6, p. 1006-10, 1999.

10. KLINGS, E. S.; FARBER, H. W. Role of free radicals in the pathogenesis of acute chest syndrome in sickle cell disease. Respir Res, v. 2, n. 5 , p. 280-5, 2001.

11. LETTRE, G. et al. DNA polymorphisms at the BCL11A, HBS1L-MYB, and $\beta$-globin loci associate with fetal hemoglobin levels and pain crises in sickle cell disease. Proc Natl Acad Sci USA, v. 105, n. 33, p. 11869-74, 2008.

12. MANFREDINI, V. et al. A fisiopatologia da anemia falciforme. Infarma, n. 1/2, v. 19, p. 3-6, 2007.

13. NAOUM, P. C. Interferentes eritrocitários e ambientais na anemia falciforme. Ver Bras Hematol Hemoter, n. 22, v. 1, p. 5-22, 2000.

14. NAOUM, P. C.; RADISPIEL, J.; MORAES, M. S. Dosagem espectrométrica de metaemoglobina sem interferentes químicos ou enzimáticos. Rev Bras Hematol Hemoter, v. 26, n. 1, p. 19-22, 2004.

15. NAOUM, P. C.; SOUZA, P. C. Avaliação dos produtos da degradação oxidativa da $\mathrm{HbS}$ nos genótipos SS, SF (S/ $\beta 0$ talassemia) e AS, em comparação com hemoglobinas normais. J Bras Patol Med Lab, v. 40, n. 4, p. 249-59, 2004.
16. NASCIMENTO, T. S. et al. Metemoglobinemia: do diagnóstico ao tratamento. Rev Bras Anestesiol, n. 58, v. 6, p. 651-64, 2008.

17. PEDROSA, A. M. Estudo de citotoxicidade, inflamação e estresse oxidativo em neutrófilos de pacientes com anemia falciforme: influência do tratamento com hidroxiureia. 2013. Dissertação (Mestrado) - Faculdade de Farmácia, Odontologia e Enfermagem, Universidade Federal do Ceará.

18. SILVA, M. C.; SHIMAUTI, E. L. T. Eficácia e toxicidade da hidroxiureia em crianças com anemia falciforme. Rev Bras Hematol Hemoter, n. 28, v. 2, p. 144-8, 2006.

19. SILVA FILHO, I. L. et al.Triagem de hemoglobinopatias e avaliação da degeneração oxidativa da hemoglobina em trabalhadores portadores do traço falciforme (HbAS), expostos a riscos ocupacionais. Rev Bras Hematol Hemoter, v. 27, n. 3, p. 183-7, 2005.

20. SILVA-PINTO, A. C. et al. Clinical and hematological effects of hydroxyurea therapy in sickle cell patients: a single-center experience in Brazil. Sao Paulo Med J, n. 131, v. 4, p. 238-43, 2013.

21. STEINBERG, M. H. et al. Effect of hydroxyurea on mortality and morbidity in adult sickle cell anemia: risks and benefits up to 9 years of treatment. JAMA, v. 289, n. 13, p. 1645-51, 2003.

22. TRINDADE, K. M. Parâmetros eritrocitários, número de bospitalizações e de transfusões antes e após o uso de hidroxiureia em pacientes com sindromes falciformes acompanhados na fundação Hemopa (Pará). 2009. Trabalho de conclusão de curso - Faculdade de Biomedicina, Universidade Federal do Pará.

23. WARE, R. E. et al. Pharmacokinetics, pharmacodynamics, and pharmacogenetics of hydroxyurea treatment for children with sickle cell anemia. Blood, v. 118, n. 18, p. 4985-91, 2011.

24. ZAGO, M. A.; PINTO, A. C. S. Fisiopatologia das doenças falciformes: da mutação genética à insuficiência de múltiplos órgãos. Rev Bras Hematol Hemoter, v. 29, n. 3, p. 207-14, 2007.

\section{MAILING ADDRESS}

Marilia Rocha Laurentino

Rua Maria Consuelo, 100 G, 524; CEP: 60824-040; Fortaleza-CE, Brazil; Phone: +55 (85) 8824-0974; e-mail: marilialaurentino@gmail.com. 